(I) INCOME.

Annual recurrent Income per acre:-

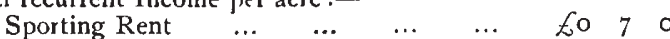

£o $7 \quad 7 \quad 0$

$(2)$

Feling Rl.ceipts-4 Acres. Total
Receipts Expenses Expenses Net Date. Age. Trees Felled. $\begin{gathered}\text { Receipts } \\ \text { including Expenses Expenses Net } \\ \text { underwood. Extraction. }\end{gathered}$

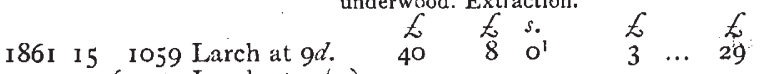

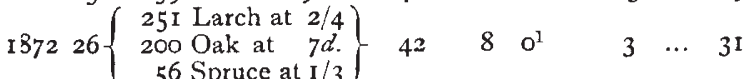
I880 $34\left\{\begin{array}{c}562 \text { Larch at } 6 / 8 \\ 174 \text { Oak at } 2 / 5 \\ 40 \text { Spruce at } 2 / 2\end{array}\right\} \quad 85\left\{\begin{array}{c}\text { Felling } \\ 9 \text { Io } \\ \text { Clearing } \\ 5 \text { IO }\end{array}\right\} \quad 7 \quad \ldots \quad 63$ $189246\left\{\begin{array}{c}\text { I } 43 \text { Larch at } 6 / 6 \\ \text { 100 Oak at } 4 / 4 \\ 8 \text { Spruce at } 3 / 2\end{array}\right\} \quad 76\left\{\begin{array}{c}\text { Felling } \\ 8 \text { IO } \\ \text { Clearing } \\ 4 \text { IO }\end{array}\right\} \quad 6 \quad \ldots \quad 57$ I90I $55\left\{\begin{array}{c}35 \text { Larch, } 735 \text { c. ft. } \\ 268 \text { Oak, } 4000,, \\ \text { IOSpruce,200 ," }\end{array}\right\} 240^{1} \quad 48 \quad 0^{1} \quad 22^{1} \quad \ldots \quad 170^{1}$

1 Items where estimate only was available. Such estimate must be . considered approximate only.

An account follows of some French forests near Valenciennes and Compiègne, the latter having been selected for this year's excursion of the Society. It is shown that the French coppicewith-standards of St. Amand, with a rotation of twenty-five years, produces a net annual revenue of $£ \mathrm{I} 2 s$. $8 d$. per acre, and that the splendid State forest of Retz, with an area of $32,55^{\circ}$ acres under beech and oak, produces a net annual revenue of I $7 s .7 d$. per acre, with a rotation of 150 years. Dr. Somerville, of the Board of Agriculture, the President of the English Arboricultural Society, contributes a notice on Prof. Schwappach's report on Prussian experiments with forest trees. The results most interesting to us are those obtained with Fraxinus americana, which withstands inundations better than Fraximus excelsior, and develops its foliage fourteen days later than the latter, thus escaping ordinary spring frosts. Larix leptolepis, the Japanese larch, is also said to resist insects and fungi better than the European larch, while it easily reproduces injured leaders.

A Forestry Society has just been started in Ireland, so that all parts of the British Isles are now enlisted in the cause.

W. R. FISHER.

\section{RECENT DISCOVERIES IN CHINESE TURKESTAN}

D) URING the last twelve years or so, the attention of scholars has been repeatedly arrested by remarkable discoveries of ancient Hindu manuscripts in Central Asia. In 1889 , Lieutenant Bower found an ancient birch-bark manuscript in Kuchār, in the northern portion of Chinese Turkestan. This "Bower Manuscript" was at once recognised as the oldest Indian manuscript extant. In I89I and I892, M. Petrovsky, Imperial ConsulGeneral of Russia at Kashgar, and the Rev. F. Weber, missionary in Leh, Ladakh, made no less important finds of old manuscripts in the region of Kashgar. Again, in 1897, the French traveller M. Dutreuil de Rhins found, in the vicinity of Khotan, some leaves of a very ancient birch-bark manuscript, in which M. Senart recognised fragments of a Prakrit version of the well-known Buddhist text, the Dhammapada. Meanwhile Dr. Hoernle, then principal of the Calcutta Madrasah, to whom we are indebted for a splendid edition of the "Bowe Manuscript," had drawn the attention of the Government of India to the remarkable records of ancient Hindu civilisation to be found in Central Asia, and on his recommendation inNO. I 707 , VOL. 66]
(I)

EXPenditure.

Annual recurrent Expenditure per acre:-

\begin{tabular}{|c|c|c|c|c|c|c|}
\hline Tithe Rent Che & $\ldots$ & $\cdots$ & $\cdots$ & ․ & $£ 0$ & 2 \\
\hline Land Tax ... & & $\ldots$ & $\ldots$ & .. & $\mathrm{o}$ & o \\
\hline Fencing and $\mathrm{D}$ & ing & $\ldots$ & $\ldots$ & $\ldots$ & o & I \\
\hline Rates $\quad \ldots$ & $\ldots$ & $\ldots$ & $\cdots$ & $\ldots$ & 0 & o \\
\hline Property Tax & $\ldots$ & $\ldots$ & ... & $\ldots$ & 0 & o \\
\hline Mole Catching & $\ldots$ & $\ldots$ & $\ldots$ & $\ldots$ & 0 & 0 \\
\hline Bailiff Wage & $\ldots$ & $\ldots$ & $\ldots$ & $\ldots$ & o & 2 \\
\hline & & & & & $£ 0$ & 7 \\
\hline
\end{tabular}

Moneys due at each Fell.

\begin{tabular}{|c|c|c|c|c|c|c|c|c|}
\hline Date. & & $\begin{array}{l}\text { and } 4 \text { per } \\
\text { Interest. } \\
f\end{array}$ & & $\begin{array}{l}\text { and } \\
\text { Inte } \\
\notin\end{array}$ & & $\begin{array}{l}\text { Total } \\
\text { due. } \\
£\end{array}$ & & $\begin{array}{l}\text { Balance } \\
\text { due. } \\
E\end{array}$ \\
\hline I $846-6$ I & $\ldots$ & 72 & $\cdots$ & 20 & $\ldots$ & 92 & $\ldots$ & 63 \\
\hline $1861-72$ & $\ldots$ & 97 & $\ldots$ & I 3 & $\ldots$ & I 10 & $\ldots$ & \\
\hline$\cdots$ & $\cdots$ & $\cdots$ & $\cdots$ & $\cdots$ & .. & .. & $\cdots$ & 97 \\
\hline $1872-80$ & .. & I I 8 & $\cdots$ & 9 & $\cdots$ & I 27 & $\cdots$ & \\
\hline$\cdots$ & $\cdots$ & $\cdots$ & $\cdots$ & $\cdots$ & $\cdots$ & $\cdots$ & $\cdots$ & 64 \\
\hline I $880-92$ & $\ldots$ & 102 & $\cdots$ & I 5 & $\cdots$ & I 7 & $\ldots$ & \\
\hline$\cdots$ & $\cdots$ & $\cdots$ & $\cdots$ & $\cdots$ & $\cdots$ & $\cdots$ & $\cdots$ & 00 \\
\hline $1892-1901$ & ... & 85 & $\cdots$ & 10 & $\ldots$ & 95 & $\ldots$ & \\
\hline
\end{tabular}

I90I Estimated Profit after paying balance due, $£ 75=£ 19$ per acre.

Planting Cost, £40; Rent, £I.

structions were issued to the British officials in Kashgar and Ladakh concerning the acquisition of antiquities from Chinese Turkestan, and a "British Collection of Central-Asian Antiquities" was gradually formed at Calcutta.

But all these had been more or less casual discoveries, and as soon as it became known that European officials were ready to pay high prices for such antiquities, native "treasure-seekers" made it their business to ransack the ancient sites in the desert, not without daniaging them, for manuscripts and other remains, and some of them were even unscrupulous enough to manufacture "old books" and sell them to Europeans as "antiques" unearthed in the desert. In these circumstances it became really a matter of urgency that systematic explorations, by some competent scholar, should at once be undertaken in these parts, all the more so as no part of Chinese Turkestan had ever been explored from an archæological point of view. No man could have been better fitted for this task than Dr. M. A. Stein, who, by his excellent topographical and archæological work in Kashmir and other parts of India, as well as by his scholarly edition and translation of the "Chronicles of the Kings of Kashmir," has shown that he combines the thoroughness and profound knowledge of the true scholar with the energy and hardiness, the practical experience and tact of the explorer. All students of India must feel thankful to the Indian Government for securing the services of such a man for the archæological and topographical exploration of Chinese Turkestan.

In June, I900, Dr. Stein was placed by the Government of India on a year's special duty, for the purpose of exploring the southern portion of Chinese Turkestan and more especially the region of Khotan. A Chinese passport from the Tsung-liYâmen was obtained, authorising him to travel and make excavations in Chinese territory. The Survey of India Depart. ment rendered material assistance by deputing one of the subsurveyors, Babu Ram Singh, to aceompany Dr. Stein on his travels, and by providing the necessary equipment of surveying instruments. Thus Dr. Stein was enabled, throughout the whole of his journey, to carry on geographical work along with his most interesting archæological researches.

A "Preliminary Report," after the completion of his journey, gives information about the character and scope of his explorations and their principal

1 "Preliminary Report on a Journey of Archrological and Topographical Exploration in Chinese Turkestan" By M. A. Stein, Indian Educational Service. Published under the authority of H.M.'s Secretary of State for India in Council. (London, igor.) 
results. As to the intrinsic historical value of the discoveries made there can be only one opinion. It is true their full import will only be realised after the publication of the detailed report to be expected from Dr. Stein himself, and after a thorough examination of the archroological specimens, photographs, coins and manuscripts which will occupy scholars for many years to come ; but even a perusal of the "Preliminary Report," and a glance at the illustrations and plates added to it, suffice to show that they will shed a flood of light on the history of an important period, and on the manifold relations between India and Central Asia during the first centuries of our era.

Dr. Stein left Srinagar on May 29. He travelled by the Gilgit-Hunza route, and on June 28 crossed the Kilik Pass and entered Chinese territory on the Täghdumbāsh Pämïr. A five days' journey down the valley of this Pāmir brought him to Tāshkurghān, the chief place of the Sarīkol mountain tract. Marching down the plains of Kashgar, he arrived, on July 29, safely at the capital of Chinese Turkestan. In Kashgar he made the necessary preparations for his travels in the desert, not only by organising a fresh caravan, but also by making efforts to secure the good-will of the Chinese authorities for the intended explorations. In these efforts he was assisted, not only by Mr. Macartney, the diplonnatic agent of the Government of India at Kashgar, but also by-the famous Chinese pilgrim of the seventh century, Hiuen-Tsiang. "All educated Chinese officials," writes Dr. Stein, "seem to have read or heard legendary accounts of the famous Chinese pilgrim's visit to the Buddhist kingdoms of the 'Western countries.' In my intercourse with them I never appealed in vain to the memory of the 'great monk of the T'ang dynasty' (T'ang-Sên), whose footsteps I was now endeavouring to trace in Turkestan, as I had done before in more than one part of India."

On September II, Dr. Stein left Kashgar and started on his journey to Khotan, choosing for his march to Yarkand, not the ordinary caravan route, but a track leading through the desert. After a short halt in Yarkand, he proceeded on the caravan route leading to Khotan along the southern edge of the desert, following "the same great thoroughfare by which in earlier times the trade from the Oxus region and the far West passed to Khotan and to China." A peculiar feature of this route and of the desert around Khotan are the "Tatis," as the natives call the "extensive patches of ground where the eroded loess is thickly strewn with fragments of coarse pottery, bricks, slag, and similar refuse marking the sites of villages and hamlets long ago abandoned "-an ideal marching ground for the archæological explorer. He reached Khotan town on October 12. The next four weeks were devoted to geographical work in the Kuen-luen range and Khotan mountains, whereupon he turned again to archæological interests, paying a visit to the Kohmanri ridge opposite to the village of Ujat, and examining old sites in the Khotan oasis, more especially those near the village of Yōtkan, where "treasure-seeking" has long been carried on along with jade-digging and gold-washing. Having finished the survey of ancient localities within the oasis, he started on December 7 on his way to Dandān.Uiliq, the site chosen for the first excavations in the Taklamakan desert. Marching through the desert, the small caravan, including a party of thirty labourers for the excavation work, found itseif on December 18 in the midst of the scattered ruins of Dandān. Uilig. This ruined site had been seen by Dr. Sven Hedin on his march to the Keriya Daryā, and is spoken of in the narrative of his travels as "the ancient city of Taklamakān." For fully three weeks most successful excavations were carried on by Dr. Stein amongst these ruins. On January 6, 190r, he left this neighbourhood, and marched across sand dunes, rising to a height of about 200 feet, to the Keriy a Daryä, and along the hard frozen river to the oasis and town of Keriya, in order to secure the assistance of the Amban (the Chinese district magistrate) for his further explorations. Making inquiries at Keriya about old localities, he heard of an "old town" in the desert north of the Muhammadan pilgrimage place of Imām Jafar Sādik. He set out in search of this ancient site, and reached Niya-the Ni-jang town of Hiuen-' 'siang-on January 2r. Six days later he was among the ruins of the Niya River site, as Dr. Stein, in absence of any special local designation, calls this site, where the excavations, carried on for nearly three weeks, yielded the most important results of the whole journey. At Niya he had heard of old remains to be found in the desert to the east towards Cherchen, and he set out in search of them. Marching more than a hundred miles to the east from Imäm
Jafar Sädik, he reached the point where the Endere stream is lost in the sands. A day's march further to the south-east brought him to the "old town of Endere," which was next explored. Interesting archæological remains and manuscripts were brought to light by the excavations. Some Tibetan manuscripts found here showed that the easternmost point of the exploration area had been reached. Hence Dr. Stein began to march back to Keriya and Khotan. Some 150 miles north of Keriya the ruins of Karadong-as they are called by the nomadic shepherds grazing along the Keriya Daryā-were visited and explored by Dr. Stein, before he continued his march to Khotan. The sandstorms and increasing heat warned him that work in the desert would soon become impossible. $\mathrm{He}$ hastened, therefore, to visit the ancient sites to the north-east of Khotan which had still to be explored. After examining the scanty ruins of Aksipil, some fifteen miles from the right bank of the Yurung-Kāsh opposite Khotan, he marched due north through the sands for about fourteen miles, when he reached the ancient site called Rawak by native "treasure-seekers." Here the last, but by no means the least interesting, excavations were carried on for a whole week. On April is the work was finished, and, having completed the programme of his explorations in the desert, Dr. Stein could return to the town of Khotan, where he arranged and carefully repacked his archæological finds. On May I he set out for Kashgar, where he made arrangements for his journey to Europe. He left Kashgar on May 29, and travelling through Russian Turkestan he reached, at Andijan, the terminus of the Transcaspian Railway. By it he travelled to Krasnovodsk, crossed the Caspian to Baku, and finally, on July 2, arrived in London, where he was able to deposit his important collection -twelve large boxes, containing numerous relievos, frescoes, painted tablets, and other specimens of Central Asian art, coins, manuscripts, and more than 800 negatives on glass plates, the photographic results of his journey-in the British Museum. A three months' period of deputation in London hat to suffice for the provisional arrangement and cataloguing of his precious finds and for preparing the "Preliminary Report."

It would require far more space than I could be allowed in these columns to mention only the most important results of Ur. Stein's explorations. I must content myself with just pointing out the most striking features of the discoveries recorded in the "Preliminary Report." Though archroology and historical topography were the chief interests, and the desert around Khotan was the principal area of the explorations made by Dr. Stein, he missed no opportunity, throughout the whole of his journey, to attend to general geographical work as well and to make valuable anthropological and ethnographical observations.

Thus, in the interests of geography, he superintended the survey on the Tâghdumbāsh Pāmìr and in the Sarikol mountain tract; and by choosing for his march to Kashgar the route which passes through the valleys between the Russian Pāmirs and the western slopes of the Muztāgh-Ata range, he was able to extend this survey to the Muztägh-Ata and the mountain ranges overlooking the Little Karakul Lake. Again, on his march from Kashgar to Yarkand he succeeded in fixing the position of Ordam Pādshāh more accurately than is done on the existing maps. After his arrival in Khotan he devoted a whole month to survey operations in the Kuen-luen mountain range, especially in that portion of it which contains the head-waters of the Yurung-Kâsh River. He also explored the hitherto unknuwn mountain tract towards the Karakāsh River and was able to complete the triangulation of the Khotan Mountains.

Anthropometric observations were made by Dr. Stein in all regions offering any anthropo-geographical interest, for instance among the Iranian hillmen in the Sarikol settlements. Nor did he omit to make notes of any popular legends and folklore connected with interesting localities, and often he found "old stories" which Hiuen.Tsiang had heard and recorded in the account of his travels, still alive among the population. The tenacity with which local legends survive proved often very useful in the identification of old sites. Thus, near the frontier of the Khotan district, there is a Muhammadan shrine known as Kaptar-Mazar, i.e. " the pigeon's shrine," at which thousands of pigeons are kept and propitiated by food offerings, and a legend is told of a great victory won with the help of pigeons by some Muhammadan hero over a host of Khotan unbelievers. Now Hiuen-Tsiang tells us that some thirty miles to the west of the capital of Khotan there was a range of hills supposed to have been formed by the burrowing of rats, the rats having been

$$
\text { No. I707, vol. 66] }
$$


worshipped there owing to the popular belief that in ancient Buddhist times they had saved the land by destroying the leather of the harness and armour of some hostile army. The locality indicated by the Chinese pilgrim corresponds exactly to Kaptar-Mazar, and Dr. Stein has no doubts that the pigeons of the Muhammadan legend have taken the place of the rats of the legend as related by Hiuen-Tsiang.

During the whole of his journey, Dr. Stein paid the greatest attention to historical topography. Everywhere he tried to trace and identify ancient sites mentioned by Hiuen-Tsiang and other Chinese travellers. Thus-to mention only some of the more important results-Paloyo, the Dard designation of the people of Baltistann, was identified with the term Po-liu, as used in the Chinese Annals and in the narratives of the Chinese pilgrims. Sir Henry Yule's identification of Sarikol with the K'ie-p'an-to territory of Hiuen-Tsiang was fully confirmed by Dr. Stein's investigations. On'his march to Khotan he was able to identify the small oasis of Moji with the town of Po-Kia-i, where a famous Buddha statue brought from Kashmir was worshipped in the times of Hiuen-Tsiang. Following the road once used by the Chinese pilgrim, he traced other ancient sites near the oasis of Zanguyya, and close to the frontier of the Khotan district. Two identifications, previously made by $M$. Grenard, were fully borne out by the evidence found by Dr. Stein-that of the Kohmārī ridge and cave with the ancient Gośrnga mountain and the cave where the popular legend of Hiuen-Tsiang's time supposed a Buddhist saint to reside "plunged in ecstasy and awaiting the coming of Maitreya Buddha"; and that of the village of Yötkan with the ancient capital of Khotan. Among the many proofs for the latter identification, the most convincing was that, from this starting point, Dr. Stein was able to identify the positions of the most important Buddhist shrines visited by Hiuen-Tsiang, the places of which are generally occupied now by Muhammadan Ziärats. Thus, the small hamlet of Somiya was found to correspond exactly to the Buddhist convent described by the Chinese pilgrim under the name of Sa-mo-joh. Finally, we may mention that on his march from the Karadong ruins to Keriya, Dr. Stein identified the position of the town of Pi-mo, described by Hiuen-Tsiang, in the neighbourhood of Lachim-Ata Mazar.

But it is chiefly for his archæological discoveries and his manuscript finds that Dr. Stein's journey of exploration will ever be memorable. We cannot enter here into details about the many interesting Buddhist monuments examined by Dr. Stein in the course of his travels in Gilgit, Hunza, Sarikol and Kashgar, and the antiquities collected by him on the Yarkand-Khotan route, in Khotan town and in the village of Yotkan. Also for the excavations made at the Endere site, at Karadong and at Ak-sipil we must refer the reader to Dr. Stein's "Preliminary Report." But a word or two must be said about the most important results of the excavations carried on among the ruins of Dandān. Uiliq, the Niya River site and of Rawak.

No less than fourteen detached temples and dwelling-houses were excavated in Dandān-Uiliq. First of all two temple cellas were brought to light, richly decorated with wall paintings and stucco images. The interior of the larger cella was occupied by a colossal stucco statue, probably representing a Buddha. Each of the four corners of the same cella was occupied by a draped stucco figure standing on a lotus-shaped pedestal. The cella walls were decorated, inside with frescoes showing figures of Buddhas or Buddhist saints, and outside with fresco bands containing small representations of saints, seated in an attitude of meditation. In style of composition and the drawing of figures, these wall decorations are similar to the later of the Ajanta frescoes. But as we possess only very few specimens of old Indian painting, the study of the Dandān-Uiliq frescoes will prove of particular interest. For the same reason, the small painted tablets which Dr. Stein discovered on excavating the temple cellas are of importance. They were probably votive offerings from worshippers who had come to visit the shrines in ancient times. A figure represented on one of these tablets shows the head of a rat-which is interesting in view of the legend of sacred rats mentioned above. Near the excavated buildings Dr. Stein generally found groups of shrivelled and bleached trunks of poplar and fruit trees, the remains of ancient orchards or avenues. Also traces of old irrigation channels were recognisable in the sand.

Of the manuscripts excavated at Dandann-Uiliq, the most important are some oblong leaves of paper inscribed with old
Indian Brähmī characters (i.e. the alphabet which is written from left to right, and used in the edicts of King Asoka, and similar epigraphic documents), and belonging to five different manuscripts, three of which are in Sanskrit and contain Buddhist texts. From their palæographic peculiarities Dr. Stein concludes that they cannot be later than the seventh, and may belong even to the sixth or fifth, century. Moreover, there were found single leaves of thin, coarse paper, inscribed with cursive Indian characters, but showing a non-Indian language, and some Chinese documents of similar material and appearance. Two of the latter bear dates, according to which they must have been written between 763-805 A.D. Dr. Stein thinks that these dates indicate about the time when the dwellings were abandoned. The evidence of numerous coins found in the course of excavations supports this dating of the Dandān-Uiliq ruins.

Among the most interesting discoveries in the ruins at the Niya River site, there are remains of two large dwellinghouses, excavated by Dr. Stein. In one of them some specimens of household furniture, illustrating the industrial arts of the period, were found, amongst others a wooden chair with ornamental wood carving, the decorative motives of which closely resemble those of the relievo sculptures of the Buddhist monasteries of Yusufzai and Swat (the ancient Gandhāra). In one room, the stuccoed walls of which showed a carefully executed fresco decoration, the pieces of a coloured rug-an interesting specimen of ancient textile industry-were brought to light. Again, in another of the excavated houses there were found the legs and arm-rests of a wooden chair, representing lions and human-headed monsters, and still retaining traces of colour, and also the broken end of a kind of guitar, resembling the popular "Rahāb" of modern Turkestan.

But most important of all are the manuscripts unearthed at the Niya River site. More than 500 wooden tablets inscribed with ancient Kharoshthi $\overline{1}$ characters (i.e. the alphabet written from right to left, and known chiefly from Indo-Scythian and Indo-Greek coins, found in the north-west of India) were found among the ruins of this site. Most of them are wedge-shaped, from 7 to 15 inches long, and arranged in pairs ; and some of them still retained their string and clay sealing intact, thus illustrating the ingenious manner adopted for the fastening and sealing of these documents. Other tablets were oblong, some of considerable length (up to 30 inches), resembling the Indian palm-leaf manuscripts. An ancient pen, made of tamarisk wood, with a bone knob, was found, and gives us some idea of clerical work in this remote period. A considerable number of these tablets were found in an ancient rubbish heap, and there were also some narrow pieces of wood inscribed with Chinese characters. The same rubbish heap yielded another very rare, and in a Buddhist country particularly surprising, writing material, namely, about two dozen documents written in Indian Kharoshthī characters on leather. A thorough examination of all these documents as to their contents will take much more time than Dr. Stein was able to bestow on them during his short deputation. But he could make out that most of them were written in an old Prakrit dialect with an admixture of Sanskrit terms, and the wedge-shaped tablets seem to contain correspondence, records of agreement, bonds, memoranda and the like, while religious texts, votive records, \&c., will probably be found to form the contents of the longer tablets. As to the date of these documents, palæographical evidence proves them to belong to the first centuries of our era. For the writing resembles closely that on the inscriptions of the Indo-Scythian kings who ruled over the Punjab and the Kabul region during the first two centuries, and the Kharoshthi alphabet soon ceased to be used after that period. These wooden tablets must, therefore, be considered at present as the oldest Indian manuscripts extant. The use of wood as writing material is also a proof of considerable antiquity. From the fourth century onward, the use of paper as writing material is attested for Turkestan. Yet not the smallest scrap of paper was discovered in the ruins of the Niya River site. Numismatic finds, as well as the influence of classical art shown on some of the clay seals attached to the tablets, confirm this dating.

The last excavations were those made at Rawak, where Dr. Stein found an imposing Stũpa surrounded by a court forming a quadrangle I 64 feet long and I 43 feet broad. Both inside and outside, the walls of this Stupa court were decorated with rows of colossal statues in stucco, representing Buddhas or Bodhisattvas, and between them at frequent intervals with smaller relievos

No. 1707, voL. 66] 
representing deities and saints. The whole of the relievo work had originally been coloured, and there were fresco paintings besides. The excavations of these relievos proved no easy task, as the structures threatened to collapse when the sand was removed. Yet Dr. Stein succeeded in clearing ninety-one large and numerous small relievos. Photos were taken of the larger relievos, while the smaller ones were taken to England. In style and details of execution the Rawak sculptures resemble the Græco-Buddhist sculptures of the Peshawar Valley and the neighbouring regions. Chinese copper coins, found among the ruins, proved to be coins of the Han dynasty. As the rule of the kings of this dynasty covers the period of $25^{-220} \mathrm{~A}$.D., and some of their coins are known to have been current until the close of the fourth century, we have thus a chronological limit, to which the Rawak sculptures may safely be referred.

Finally, we must at least touch upon one negative, though none the less important, result of Dr. Stein's journey of explora. tion. During his last eight days' stay at Khotan he succeeded in clearing up the doubts he had long entertained concerning the genuineness of certain very puzzling manuscripts and blockprints "in unknown characters" which had for some years past been purchased from Khotan and added to the "British Collection of Central-Asian Antiquities" in Calcutta. With the help of the Chinese authorities he got hold of the very man-one Isläm Âkhün-from whom most of these documents had been bought. The man was brought before Dr. Stein, who forced from him, in the course of a prolonged cross-examination, an open confession of his manufacture of "old books." Dr. Stein has shown that it is easy to distinguish the forgeries from genuine old manuscripts, and there is no fear that any scholar will, in future, be deceived into trying to decipher the " unknown characters" of Khotan manuscripts.

This brief sketch will suffice to give an idea of the singular importance of the discoveries made by Dr. Stein. But the costly treasures brought by him from Chinese Turkestan will require the most careful examination and study to be made fruitful for further research, and who could be better fitted for this task than the happy discoverer himself? While congratulating both the Indian Government and Dr. Stein on the brilliant discoveries made in Central Asia, we can only express our sincerest hope that the authorities of the India Office may see their way to grant Dr. Stein the leisure required for completing the work so happily begun, in order that the present "Preliminary Report" may soon be followed by a Detailed Report of Dr. Stein's tried workmanship.

\section{WINTERNITZ.}

\section{UNIVERSITY AND EDUCATIONAL INTELLIGENCE.}

THE authorities of Reading College have received an intimation that the Treasury recommends the advancement of the College to the list of University Colleges, with a Government grant of 1000 . a year for five years. The grant will be subject to the Treasury audit, but local subscribers have assured the necessary income.

PRof. Hewlet', director of the Department of General Pathology and Bacteriology at King's College, London, has arranged a vacation course in practical and clinical bacteriology to commence Wednesday, August 6, and end Saturday, August 16. The course will consist of lectures, demonstrations and practical work; in the latter, the members of the class will make for themselves permanent preparations of the chief pathogenic micro-organisms and will carry out the principal manipulations employed in bacteriological investigations.

A MEETING of numerous representatives of primary, secondary (including technical) and other branches of education was recently held at the Municipal School of Technology, Manchester, to consider whether arrangements should be made for a conference of science teachers in the north of England on the lines of those established by the Technical Education Board of the London County Council, which have been held in London during the Christmas vacation for some years past. The proposal to hold similar conferences in the north of England was unanimously adopted, and a committee formed to make the necessary arrangements. The first conference will be held on Friday and Saturday, January 2 and 3, 1993, at Manchester.

$$
\text { No. I707, vOL. 66] }
$$

A LIST of requirements and courses at the Clarkson Memorial School of Technology, Potsdam, New York State, has been received. The institution was founded in 1895 to provide technological education of college standard, and is a constituent college of the University of the State of New York. It is of interest to note that the regular courses of work extend over four years and that satisfactory evidence of thorough preparation must be given by students who wish to enter the college. Now that the London polytechnics are part of the University of London, efforts should be made to introduce or extend the same kind of regulations as to systematic work and preliminary studies.

HrThERTO none of the technical institutes has been specially organised for the optical trades, though optical classes have been held in several of them, notably in the Northampton Institute in Clerkenwell. But the optical trades appear to have awakened to the need of specialised instruction of the highest kind for the young men in their industry, and a movement to create a real Optical Institute is on foot. The Optical Society has approached the Technical Education Board of the London County Council to urge upon it the creation of such an establishment. If the Techn ical Education Board could see its way to organise and equip a special technical school in optics, and endow it with a grant of 3000 l. or 4000 . a year, we might expect great things for the future of the optical trades. When it is remembered how greatly the electrical industries of Great Britain have benefited by the electrical teaching and the electrical laboratories established twenty years ago by the City and Guilds Institute, one wonders why similar optical laboratories, properly equipped for the teaching of technical optics, have not been long ago organised. The present movement is a sign that England is waking up.

\section{SOCIETIES AND ACADEMIES. \\ LONDON.}

Royal Society, February I3.- "The Refractive Indices of Fluorite, Quartz and Calcite." By J. William Gifford. Communicated by Prof. Silvanus P. Thompson, F.R.S.

Tables are given of the refractive indices of the above substances for twenty-six wave-lengths, from wave-length 7950 $\mathrm{Rb}$ to wave-length $185^{2} \mathrm{Al}$ inclusive at $15^{\circ} \mathrm{C}$., and of the temperature refraction coefficients. To ensure accuracy a new method of observation was adopted. The prisms were polished on three sides, and deviations were measured at each of the three angles. The indices were calculated by the formula $\mu=\sin \frac{1}{2}\left(D+60^{\circ}\right) / \sin 30^{\circ}$.

The difference of the angles of the prisms from $60^{\circ}$ were in each case less than 4 seconds of arc. When this is the case the error introduced is less than $0^{\circ} 000000 \mathrm{I}$ in the index. It is not, therefore, necessary to measure the angles with accuracy. Some of the rays from the collimator are reflected from the base of the prism and enter the telescope. The image of the slit thus obtained coincides with the refracted image only when minimum deviation is reached. In cutting the goniometer circle a burr is thrown up by the engraving tool on each side of every division. By two small electric lamps behind the reading microscope either or both burrs are made to appear as fine white lines. With the help of quartz fibres measurements are made on these and the mean taken. A correction is made for the error of the reading microscope, and special precautions have been taken to ensure the optical correctness of the prisms. An exact copy of the original measurements for line $\mathrm{C}$ fluorite is given. An approximate estimate of the total error gave for the II 9 indices in the table,

$$
\begin{array}{cccc}
33 & \text { less than } . . . & \ldots & 0.0000023 \\
39 \quad, \quad & \ldots & \ldots & 0.0000034 \\
3 \text { I } \quad, \quad \ldots & \ldots & 0.0000084 \\
\text { I5 more than } & \ldots & 0.0000084 \\
\text { I only as great as but } & 0.0000 \text { I } 50
\end{array}
$$

Some indices for left-handed quartz are given, and a rough determination of the specific gravities of right and left quartz. The partial and proportional dispersions of fluorite, quartz and calcite for the visual spectrum and their lens combinations are also given, together with a list of focal lengths for unity and a table of curves for the whole spectrum with ordinates for a mean focal length of six thousand nine hundred and eightyfive millimetres. 